\title{
DISTRIBUTION OF ANTIOXIDANT COMPONENTS IN ROOTS OF DIFFERENT RED BEETS (BETA VULGARIS L.) CULTIVARS
}

\author{
D. Székely*, L. Szalóki-Dorkó, M. Stéger-Máté, B. Szabó-Nótin, J. Ivanics and \\ J. MONSPART-SÉNYI \\ Department of Food Preservation, Faculty of Food Science, Corvinus University of Budapest, \\ H-1118-Budapest, Villányi út 29-43. Hungary
}

(Received: 15 April 2014; accepted: 5 August 2014)

\begin{abstract}
The beetroot is typically on the table in winter in form of pickles or juice, but for its nutritional values it would deserve more common consumption. Its curative effect in great part is due to the several vitamins, minerals, and compounds with antioxidant activity. But the division of biological active compounds is very different in the parts of the root. Based on our results, we could compare the differences between the morphology and some inner contents (soluble solid content, colour, betacyanin, betaxanthin, and polyphenol contents, antioxidant activity, and some flavonoids) of two beetroot cultivars. The results of the morphological investigations showed that the 'Cylindre' cultivar had more favourable crop parameters than the 'Alto F1' cultivar. In the 'Cylindre' cultivar the polyphenol content and the antioxidant capacity were significantly higher than in the 'Alto F1' cultivar. By determination of the betanin contents of the investigated beetroots, our results showed both betacyanin and betaxanthin contents were higher in the 'Cylindre' cultivar. The chlorogenic acid, gallic acid, the cumaric acid have been identified based on the peaks of HPLC in the studied beetroot cultivars.
\end{abstract}

Keywords: beetroot, antioxidant capacity, polyphenol content, betacyanin, betaxanthin, flavonoids

The beetroot is native to the Mediterranean area and ancestor of the wild form of Beta vulgaris L. var. maritime. The Greeks and Romans knew and cultivated and consumed the beetroot in the $2^{\text {nd }}-3^{\text {nd }}$ centuries. It became known in Hungary in the $17^{\text {th }}$. century.

The beetroot is one of the ten most powerful vegetables regarding antioxidant capacity. The polyphenol content for the total dry matter is $50-60 \mathrm{~mol} \mathrm{~g}^{-1}$ (VINSON et al., 1998; KAHKONEN et al., 1999).

Its curative effect in great part is due to the numerous vitamins (C-, B vitamins, folic acid and beta carotenes among others) and high mineral content (iron, copper, magnesium, and calcium). BERRADA and co-workers (2007) have determined the $\mathrm{K}, \mathrm{Cl}, \mathrm{P}, \mathrm{Mg}$, and $\mathrm{Na}$ contents in natural red beet by $14 \mathrm{MeV}$ neutron activation analysis.

Kujala and his colleagues determined that the total phenol content of beetroot is decreasing towards the inside of the beet body. Fifty percent of the total phenol content is in the peel, $37 \%$ is in the crown, and $13 \%$ is in the body. Betalain content of the crown is $32 \%$ and of the root is $14 \%$ (KuJALA et al., 2000). The valuable colour contents of the beetroot are nitrogen-containing, water-soluble pigments, these are the betalains. These can be divided into two main groups; the red betacyanins and the yellow betaxanthins. The major betacyanin pigment in the beetroot is betanin, which is a betanidin-5-O- $\beta$-glucoside. The betanidin is the aglycolic form of the betanin. The major betaxanthin is the vulgaxanthin in the red beet (KugLer et al., 2007). The beetroot also contains anthocyanins, which are responsible for the

* To whom correspondence should be addressed.

Phone: +36-1-482-6035, fax: +36-1-482-6327, e-mail: dora.szekely@uni-corvinus.hu

0239-3006/\$20.00 C 2014 Akadémiai Kiadó, Budapest 
shades of red. For red and yellow beets it has been proved that the red pigments have higher free radical scavenging capacity than the yellow ones, and it increases continuously with the pH of the fluid (PEDRENO et al., 2001).

Clinical research results of KAPADIA and co-workers (2011) show that the growth of prostate and breast cancer cells slows down by $12 \%$ due to the betacyanin effect. NAGYGASZTONYI and co-workers (2005) investigated the water soluble nitrate content of various red beet cultivars. It was measured as a function of irrigation and mineral supplementation for three years. In the first year, the nitrate content increased in the roots following the irrigation. The activity of nitrate-reductase in the leaves was also significantly higher after irrigation in different red beet cultivars. The mineral supplementation increases the nitrate content in most of the carrot cultivars. The impact of water supply showed various tendencies in nitrate accumulation in different red beets. The results of three years showed that the seasonal and cultivar-related differences were also remarkable.

The aim of our study was to investigate the different antioxidant compounds in two beetroot cultivars for comparing them in different parts of the root.

\section{Material and methods}

\subsection{Plant materials}

For the experiment, the autumn sowing of 'Cylindre' and 'Alto F1' cultivars were grown in conventional soil by the Experimental and Research Farm of Department of Vegetables and Mushroom Growing (Corvinus University of Budapest). Following the harvest of 10-10 plants per cultivars, the beets were washed, cleaned, and the morphological investigations were carried out. The weight of ten beetroots was weighed with digital scale and the length of ten beetroots was determined with a calliper. From the top and the end of the beetroots slices of $2-2 \mathrm{~cm}$ were cut, so the beetroots were cut into three parts: top, middle, and end parts. The three parts were treated separately. The beets were peeled and chopped. The mash was made from comminuted raw material with a mixer, and the pressing was realized by mechanical process, compression.

\subsection{Analytical methods}

Determination of soluble solids content was carried out by 558/1993/EEC using the refractometric measurement method (DBX ATAGO ATAGO and PR-301 models). Measurements were carried out by measuring three parallel replicates.

The colour measurement was realized with Konica Minolta CR 400 type handheld digital colour measuring device, which is based on the CIELab system. The L* (lightness factor), $a^{*}$ (the transition from red to green), and $b^{*}$ (from blue to yellow) values were determined.

Total phenol content was measured using Folin-Ciocalteu's reagent according to the method of SingLETON and Rossi (1965). Absorbance was monitored spectrophotometrically at $760 \mathrm{~nm}$, and the content of soluble phenols was calculated from a standard curve based on gallic acid (GA) concentrations. Results were provided in $\mathrm{mg} \mathrm{ml}^{-1}$ dimension.

Determination of the antioxidant capacity was carried out by the FRAP method. FRAP assay was conducted spectrophotometrically at $593 \mathrm{~nm}$ according to BENZIE and STRAIN 
(1996). FRAP value was calculated relevant to the activity of ascorbic acid (AA) and expressed as ascorbic acid equivalents. Results were provided in $\mathrm{mg} \mathrm{AA} / \mathrm{ml}$ dimension.

Determination of betacyanin and betaxanthin contents were carried out according to the spectrophotometric method by CASTELLAR and co-workers (2003) and STINTZING and coworkers (2005). The absorbancy of the sample solutions diluted to $2 \mathrm{ref} \%$ was measured on $535 \mathrm{~nm}$ and $484 \mathrm{~nm}$. Distilled water was used for blank samples. Results were provided in

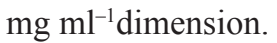

For the HPLC measurements, $500 \mu \mathrm{l}$ beetroot juice was dissolved in $9.5 \mathrm{ml} 20 \%$ methanol and the samples were filtered. The separation of the phenolic components was done with Shimadzu HPLC instrument. The HPLC equipment consists of a gradients pump (LC 10), an UV-Vis detector (SDP-10A), a degasser (DGU-20A9), a column-thermostating unit (CTO-10A), a control unit (CBM-20A), and a computer software (LC Solution Software) that makes the processing and analysis of data easier. A reversed phase $\mathrm{C} 18$ column (Supelco, $250 \times 4,6 \mathrm{~mm}$ i.d., $5 \mu \mathrm{m})$ was used for the HPLC investigation of flavonoids. The column operated optimally at $40{ }^{\circ} \mathrm{C}$. The eluent was $2 \% \mathrm{v} / \mathrm{v}$ acetic acid and $2 \% \mathrm{v} / \mathrm{v}$ acetic acid:acetonitrile 30:70 gradient. The amount of solvent changed depending on the applied gradient eluent (changing of the composition of mobile phase during the measurements). The necessary time was 40 minutes for the recording of chromatograms. The injected volume was $20 \mu \mathrm{l}$ in case of each sample. The flow rate was $1.5 \mathrm{ml} \mathrm{min}^{-1}$. The investigation was carried out on $310 \mathrm{~nm}$ wavelength. The stock solutions of standard phenolic components were $2 \mathrm{mg} \mathrm{ml}^{-1}$ in methanol, which were stored at $-18^{\circ} \mathrm{C}$. Measurements were done in triplicates.

\subsection{Statistical methods}

Statistical evaluation was performed using Student's $t$-test of Microsoft Excel. The values of the middle part of both beet cultivars were compared with the top and the end part in case of polyphenol content, antioxidant capacity, and betacyanin and betaxanthin contents by Student's $t$-probe. The values of the different 'Cylindre' parts were compared with the different 'Alto F1' parts in case of polyphenol content, antioxidant capacity, and betacyanin and betaxanthin contents by Student's t-probe.

\section{Results and discussion}

By the comparison of morphological characteristics of the two beetroot cultivars, the average weight of the 10 pieces of the 'Cylindre' cultivar was $3.955 \mathrm{~kg}$, and the average weight of the 10 pieces of the 'Alto F1' cultivar was $2.985 \mathrm{~kg}$. The average length of the 10 pieces of the 'Cylindre' cultivar was $0.590 \mathrm{~m}$, and the average length of the 10 pieces of the 'Alto F1' cultivar was $0.495 \mathrm{~m}$.

In case of the water soluble solids content of the investigated beet cultivars, the 'Cylindre' cultivar showed higher values (10.67 ref\%) than 'Alto F1' cultivar (6 ref\%). For 'Cylindre' the maximum value was in the end of the body (12 ref\%), and for the 'Alto F1' cultivar the highest soluble solids content was in the middle of the body (8\%) (Fig. 1).

Table 1 shows the results of the colour measurements. In case of the 'Cylindre' the $\mathrm{L}^{*}$ and the $\mathrm{a}^{*}$ values were the highest in the top of the body, and both values decreased towards the end of the body. The $b^{*}$ value was the highest in the middle of the body, slightly lower in 
the top of the body, and the lowest $b^{*}$ value was in the end of the body. In case of the "Alto F1' the L* values were the same in the middle and end of the body, and this value was slightly lower in the top of the body. The $\mathrm{a}^{*}$ and the $\mathrm{b}^{*}$ values were the highest in the middle of the body and lowest in the top of the body.

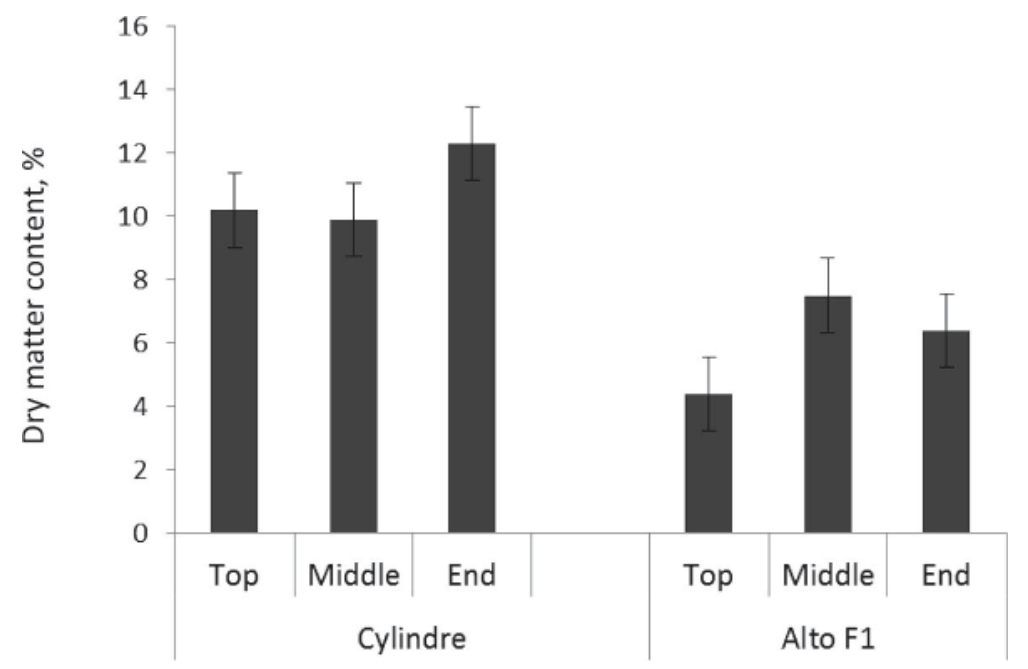

Fig. 1. Water soluble solids content of the investigated beetroot cultivars

Table 1. $\mathrm{L}^{*}, \mathrm{a}^{*}$ and $\mathrm{b}^{*}$ values of the investigated beetroot cultivars

\begin{tabular}{lccccccccc}
\hline \multirow{2}{*}{$\begin{array}{l}\text { Beetroot } \\
\text { cultivars }\end{array}$} & \multicolumn{3}{c}{$\mathrm{L}^{*}$} & \multicolumn{3}{c}{$\mathrm{a}^{*}$} & \multicolumn{3}{c}{$\mathrm{b}^{*}$} \\
\cline { 2 - 10 } & Top & Middle & End & Top & Middle & End & Top & Middle & End \\
\hline \multirow{2}{*}{ Cylindre } & $\mathrm{X}: 20.74$ & 20.52 & 19.57 & 2.47 & 2.35 & 2.13 & 1.56 & 1.65 & 0.64 \\
& $\mathrm{SD}: \pm 0.17$ & \pm 0.24 & \pm 0.77 & \pm 0.06 & \pm 0.02 & \pm 1.17 & \pm 0.07 & \pm 0.13 & \pm 0.07 \\
\multirow{2}{*}{ Alto F1 } & $\mathrm{X}: 20.20$ & 20.47 & 20.47 & 1.03 & 2.52 & 2.22 & 1.31 & 1.63 & 1.48 \\
& $\mathrm{SD}: \pm 0.16$ & \pm 0.26 & \pm 0.48 & \pm 0.14 & \pm 0.03 & \pm 0.07 & \pm 0.11 & \pm 0.01 & \pm 0.17 \\
\hline
\end{tabular}

$\mathrm{X}$ : average; SD: standard deviation; $\mathrm{L}^{*}$ : lightness factor; $\mathrm{a}^{*}$ : red/green; $\mathrm{b}^{*}$ : blue/ yellow

In the 'Cylindre' cultivar the polyphenol content was significantly higher (average value: $1.347 \mathrm{mg} \mathrm{ml}^{-1}$ ), about double, than by the 'Alto F1' cultivar (average value: $0.682 \mathrm{mg}$ $\mathrm{ml}^{-1}$ ) (Fig. 2). In case of the 'Cylindre' samples, the polyphenol content was almost the same in the top and middle of the body, and in the end of the body this value was slightly higher $\left(1.449 \mathrm{mg} \mathrm{ml}^{-1}\right)$. In case of the 'Alto F1' samples, the polyphenol content increased from the top $\left(0.497 \mathrm{mg} \mathrm{ml}^{-1}\right)$ to the end of the body $\left(0.839 \mathrm{mg} \mathrm{ml}^{-1}\right)$. Ninfali and Angelino (2013) found $1.77 \pm 0.08 \mathrm{~g} \mathrm{~kg}^{-1} \mathrm{DW}$ total phenols concentration in Beta vulgaris rubra root using a different sample preparation. 


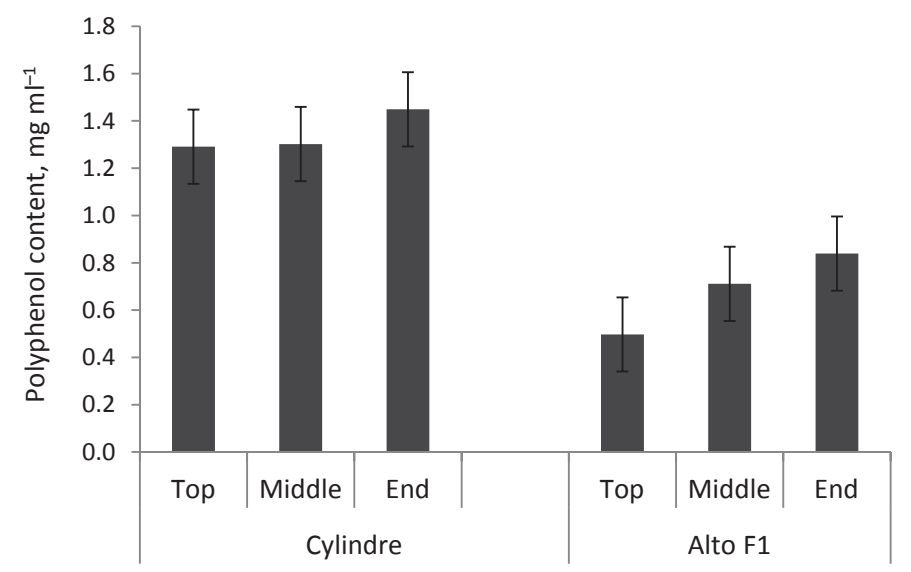

Fig. 2. Polyphenol content of the investigated beetroot cultivars

For the 'Cylindre' cultivar the antioxidant capacity was significantly higher (the average value: $0.85 \mathrm{mg} \mathrm{AA} / \mathrm{ml}$ ) than for 'Alto F1' $(0.56 \mathrm{mg} \mathrm{AA} / \mathrm{ml})$. In case of both beetroot cultivars the lowest antioxidant capacity was in the middle of the body $(0.72$ and $0.45 \mathrm{mg} \mathrm{AA} / \mathrm{ml})$. The highest value was for 'Cylindre' cultivar in the end of the body $(0.93 \mathrm{mg} \mathrm{AA} / \mathrm{ml})$, while in case of 'Alto F1' cultivar in the top of the body (0.67 mg AA/ml) (Fig. 3).

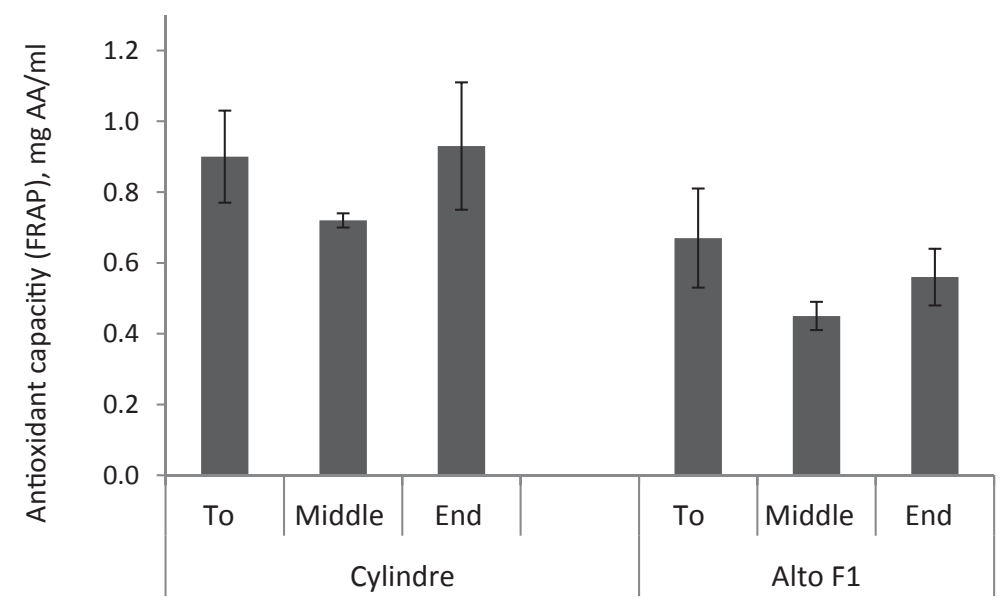

Fig. 3. Antioxidant capacity of the investigated beetroot cultivars

By determination of the betanin content of the investigated beetroots our results showed that both betacyanin and betaxanthin contents were higher in the 'Cylindre' cultivar (Fig. 4). Distribution of both compounds in the roots is the same in case of both beet cultivars, the end of 'Cylindre' contains the highest values (betacyanin content: $0.245 \mathrm{mg} \mathrm{ml}^{-1}$; betaxanthin 
content: $0.165 \mathrm{mg} \mathrm{ml}^{-1}$ ) and the top of 'Alto $\mathrm{F} 1$ ' contains the lowest values (betacyanin content: $0.087 \mathrm{mg} \mathrm{ml}^{-1}$; betaxanthin content: $0.058 \mathrm{mg} \mathrm{ml}^{-1}$ ). NILSSON (1970) found betacyanin and betaxanthin concentrations in different red beet cultivars in the range of $0.04-0.21 \%$ and $0.0-0.14 \%$, respectively. while KUGLER and co-workers (2007) reported 0.721 and $0.297 \mathrm{~g} \mathrm{~kg}^{-1}$ betaxanthin in fresh weight of red and yellow beetroot.

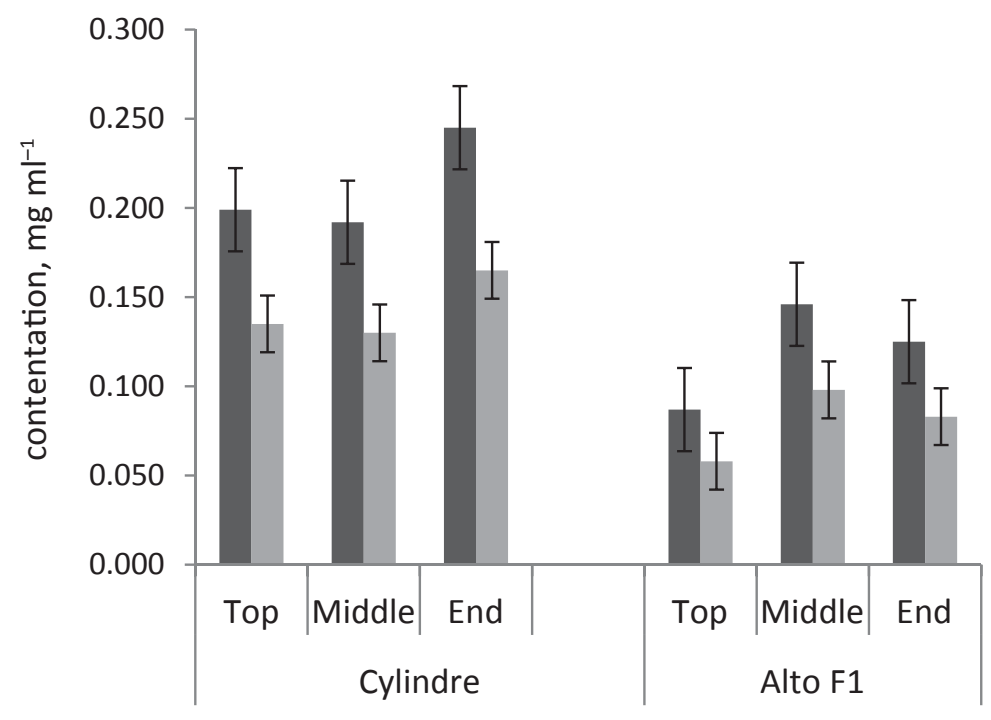

Fig. 4. Betacyanin and betaxanthin contents of the investigated beetroot cultivars.

$\square$ : bethacyanin; $\square$ : betaxanthin

The colourless flavonoids were investigated by HPLC measurements in 'Cylindre' and 'Alto F1' beetroot cultivars for the three parts of root. The investigated colourless flavonoids were as follows: chlorogenic acid $\left(\mathrm{t}_{\mathrm{ret}}=7.965\right)$, gallic acid $\left(\mathrm{t}_{\mathrm{ret}}=4.488\right)$, cumaric acid $\left(\mathrm{t}_{\text {ret }}=11.135\right)$, rutin $\left(\mathrm{t}_{\text {ret }}=13.512\right)$, quercetin $\left(\mathrm{t}_{\text {ret }}=21.957\right)$, syringic acid $\left(\mathrm{t}_{\text {ret }}=9.327\right)$, and catechin $\left(\mathrm{t}_{\text {ret }}=7.700\right)$. In the studied beetroot cultivars the chlorogenic acid, gallic acid, and the cumaric acid have been identified based on the peaks obtained by HPLC. In case of the 'Alto F1' colourless flavonoids could not be identified in the end of the root body, while chlorogenic acid could be measured in the middle and the top of 'Alto F1' root bodies (Fig. 5). In the top of the root cumaric acid could also be detected. The middle of the 'Cylindre' root body contained chlorogenic acid and gallic acid, which could be detected in the top of 'Cylindre' root body, too. Table 2 shows the quantity of cumaric acid, chlorogenic acid, and gallic acid in the different parts of 'Cylindre' and 'Alto F1' red beet cultivars. In case of 'Cylindre' and 'Alto F1' red beets chlorogenic acid, cumaric acid, and gallic acid were determined in concentrations ranging from 0.00235 to $0.0655 \mathrm{mg} \mathrm{ml}^{-1}$. Georgiev and co-workers (2010) determined the presence of 4-hydroxybenzoic acid, caffeic acid, and chlorogenic acid in concentrations ranging from 0.047 to $0.12 \mathrm{mg} \mathrm{g}^{-1}$ of dry extract in red beetroot.

Further investigations are needed with HPLC to determine the quantity of colourless flavonoids, so calibration is necessary for the investigated standards. In addition, the list of tested flavonoids should be expanded to identify further peaks of the chromatograms. 


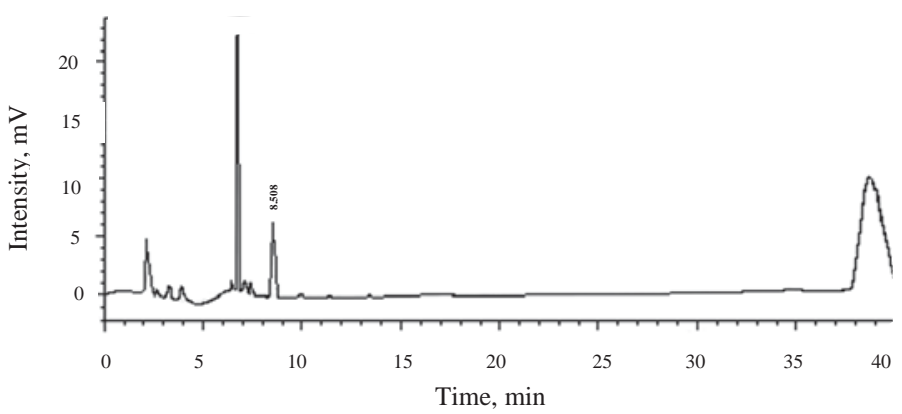

Fig. 5. Chromatogram of the middle part of 'Alto 1' cultivar. The retention time was 8.508 min for chlorogenic acid

Table 2. Quantity of flavonoids in the different parts of red beet varieties

\begin{tabular}{lcc}
\hline Flavonoids & Part of the red beet cultivars & Quantity, mg ml \\
\hline Chlorogenic acid & 'Alto F1' - Middle & 0.0323 \\
& 'Alto F1' - Top & 0.00235 \\
Cumaric acid & 'Cylindre' - Middle & 0.006 \\
Gallic acid & 'Alto F1' - Top & 0.00349 \\
& 'Cylindre' - End & 0.01637 \\
\hline
\end{tabular}

The results of the statistical analysis are shown in the Tables 3 and 4 .

Table 3. Result of Student's t-probe comparing the values of the middle part with the top and the end part in case of polyphenol content, antioxidant capacity, betacyanin and betaxanthin contents

\begin{tabular}{|c|c|c|c|c|c|c|c|c|}
\hline & \multicolumn{2}{|c|}{ Polyphenol } & \multicolumn{2}{|c|}{ Antioxidant capacity } & \multicolumn{2}{|c|}{ Betacyanin } & \multicolumn{2}{|c|}{ Betaxanthin } \\
\hline & $\begin{array}{l}\text { Top- } \\
\text { middle }\end{array}$ & $\begin{array}{l}\text { End- } \\
\text { middle }\end{array}$ & $\begin{array}{l}\text { Top- } \\
\text { middle }\end{array}$ & $\begin{array}{l}\text { End- } \\
\text { middle }\end{array}$ & $\begin{array}{l}\text { Top- } \\
\text { middle }\end{array}$ & $\begin{array}{l}\text { End- } \\
\text { middle }\end{array}$ & $\begin{array}{l}\text { Top- } \\
\text { middle }\end{array}$ & $\begin{array}{l}\text { End- } \\
\text { middle }\end{array}$ \\
\hline 'Cylindre' & 0.343 & $0.039 *$ & $0.002 *$ & 0.082 & $0.027 *$ & $0.006^{*}$ & $0.046^{*}$ & $0.003 *$ \\
\hline 'Alto F1' & 0.144 & 0.115 & 0.055 & 0.098 & $0.011 *$ & $0.008 *$ & $0.008^{*}$ & $0.013 *$ \\
\hline
\end{tabular}

*: there is significant difference between the samples at $\mathrm{P}<0.05$

Table 4. Result of Student's t-probe comparing the values of the different 'Cylindre' parts with the different 'Alto F1' parts in case of polyphenol content, antioxidant capacity, betacyanin and betaxanthin contents

\begin{tabular}{lcccc}
\hline & Polyphenol & $\begin{array}{c}\text { Antioxidant } \\
\text { capacity }\end{array}$ & Betacyanin & Betaxanthin \\
\hline 'Cylindre' top - 'Alto F1' top & 0.010 & 0.009 & 0.004 & 0.003 \\
'Cylindre' middle - 'Alto F1' middle & 0.026 & 0.000 & 0.006 & 0.010 \\
'Cylindre' end - 'Alto F1' end & 0.010 & 0.004 & 0,006 & 0.000 \\
\hline
\end{tabular}




\section{Conclusion}

The results of the morphological investigations showed that 'Cylindre' produced more favourable crop parameters than 'Alto F1' cultivar.

In case of the investigated properties, more favourable values could be shown for the 'Cylindre' cultivar. The distribution of the constituents studied was not equal in the root body. Based on these measurements, the growing of the 'Cylindre' cultivar is recommended, but this was a preliminary experiment, so further measurements are needed, such as element content and more colourless flavonoids, to give a reliable statement.

The authors acknowledge the financial help of TÁMOP 4.2.1./B-09/1/KMR-2010-0005 grant and the Experimental and Research Farm of Department of Vegetables and Mushroom Growing (CUB).

\section{References}

Benzie, I.I.F. \& Strain, J.J. (1996): The ferric reducing ability of plasma (FRAP) as a measuring of "antioxidant power": The FRAP assay. Annal. Biochem., 239, 70-76.

Berrada, M., Misdaq, M.A. \& Thallouarn, P. (2002): Kinetics of penetration and exsorption of K, Cl, Mg, Na and $\mathrm{P}$ in red beet cells by $14 \mathrm{MeV}$ neutron activation analysis. J. Radioanal. Nuclear Chem., 62, 103-113.

Castellar, R., Obon, J.M., Alacid, M. \& Fernández-Lopez, J.A. (2003): Color properties and stability of betacyanins from Opuntia fruits. J. Agric. Food Chem., 51, 2772-2776.

Georgiev, V.G., Weber J., Kneschke, E.M., Denev, P.N., Bley, T. \& Pavlov, A.I. (2010): Antioxidant activity and phenolic content of betalain extracts from intact plants and hairy root cultures of the red beetroot Beta vulgaris cv. Detroit dark red. Plant Foods Hum. Nutr., 65, 105-111.

Kahkonen, M.P., Hopia, A.I., Vuorela, H.J., Rauha, J., Pihlaja, T.S. \& Heinonen, M. (1999): Antioxidant activity of plant extracts containing phenolic compounds. J. Agric. Food Chem., 47, 3954-3962.

Kapadia, G.J., Azuine, M.A., Rao, G.S., Arai, T., IidA, A. \& Tokuda, H. (2011): Cytotoxic effect of the red beetroot (Beta vulgaris L.) extract compared to doxorubicin (adriamycin) in the human prostate (PC-3) and breast (MCF-7) cancer cell lines. AntiCancer Agents Med Chem., 11, 280-284.

Kugler, F., Graneis, S., Stintzing, F.C. \& Carle, R. (2007): Studies on betaxanthin profiles of vegetables and fruits from the Chenopodiaceae and Cactaceae. Z. Naturforsch C., 62, 311-318.

Kujala, T.S., Loponen, J.M., KiKa, K.D. \& Pihlaja, K. (2000): Phenolics and betacyanins in red beetroot (Beta vulgaris) root: distribution and effect of cold storage on the content of total phenolics and three individual compounds. J. Agric. Food Chem., 48, 5338-5342.

Nagy-Gasztonyi, M., Kardos-Neumann, Á. \& Takács-Hásos, M. (2005): Characterization of red beet and carrot with special emphasis on nitrate accumulation. Acta Alimentaria, 35, 131-138.

Nilsson, T. (1970). Studies into the pigments in beetroot (Beta vulgaris L. ssp. vulgaris var. rubra L.). Lantbrukhogskolans Annaler, 36, 179-219 -ref.: AzEREDO, H.M.C. (2009): Betalains: properties, sources, applications, and stability - a review. Int. J. Food Sci Tech., 44, 2365-2376.

Ninfali, P. \& Angelino, D. (2013): Nutritional and functional potential of Beta vulgaris cicla and rubra. Fitoterapia, 89, 188-199.

Pedreno, M.A. \& Escribano, J. (2001): Correlation between antiradical activity and stability of betanine from Beta vulgaris L roots under different pH, temperature and light conditions. J. Sci. Food Agric., 81, 627-631.

Singleton, V.L. \& Rossi, J.A. (1965): Colorimetry of total phenolics with phosphomolybdic-phosphotungstic acid "reagents". Am. J. Enol. Vitic., 16, 144-158.

Stinzing, F.C. Herbach, K.M., Mosshammer, M.R., Carle R., Yi, W., Sellappan, S., Akoh, C.C., Bunch, R. \& FELKeR P. (2005): Color, betalain pattern, and antioxidant properties of cactus pear (Opuntia spp.) clones. J. Agric. Food Chem., 53, 442-451.

Vinson, J.A., Hao, Y. \& Zubic, S.K. (1998): Food antioxidant quantity and quality in foods: vegetables. J. Agric. Food Chem., 46, 3630-3634. 